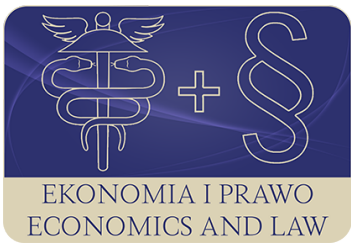

EKONOMIA I PRAWO. ECONOMICS AND LAW

Volume 18, Issue 4, December 2019

p-ISSN 1898-2255, e-ISSN 2392-1625

www.economicsandlaw.pl

ORIGINAL ARTICLE

received 30.03.2019; revised 12.12.2019; accepted 31.12.2019

Citation: Szara, K. (2019). Technology as a stimulus for the development of creative capital at the local level on the example of municipalities of the Podkarpackie Voivodeship. Ekonomia $i$ Prawo.

Economics and Law, 18(4): 499-514. doi:10.12775/EiP.2019.033.

\title{
Technology as a stimulus for the development of creative capital at the local level on the example of municipalities of the Podkarpackie Voivodeship
}

\author{
KATARZYNA SZARA \\ University of Rzeszów, Institute of Economics and Finance, ul. M.Ćwiklińskiej 2, 35-601 Rzeszów, \\ Poland \\ ๑33ksz@wp.pl \\ Dorcid.org/0000-0003-1687-0505
}

\begin{abstract}
Motivation: Development is influenced by various determinants whose strength, direction and range of influence change over time. Creative capital is considered to be a variable that affects the development of countries and cities. The concept of creative capital results from the theory of R. Florida, which defines them by presenting the assumptions of the creative class. Both technology, talent and tolerance are factors that affect local development but, according to the concept mentioned above, they also stimulate the development of creative capital.

Aim: The purpose of the paper is to assess technology as determinants of the development of creative capital in the communes of the Podkarpackie Voivodeship.

Results: The author's modification of Florida's methodology related to one of the criteria, i.e. technology is a novelty in the research approach is. It is also a new approach to technology analysis as determinants not only of local development but also of creative capital at the local level. Features indicating technology assessed using statistical data place the Podkarpackie Voivodeship in a lower position compared to the whole country. Only the share of newly registered creative sector entities is close to the result for Poland. The assessment, which applied indirect measures, shows that technological conditions in municipalities to the largest extent describe the ability of people to use specialized knowledge
\end{abstract}


in the municipality in their work and personal life. Technology, which determines development, and also indicates the advancement of society, is important at the global level but also at the local level as evidenced by responses regarding openness to new technologies. The comparison of both groups of respondents shows that the possibilities of developing creative capital through the lens of features describing technology were rated by residents of municipalities rather than officials.

Keywords: technology; creative capital; commune; Podkarpacie

JEL: R11; R12; R5

\section{Introduction}

When analyzing the development literature, it should be agreed that the concept is ambiguous and used in various contexts. It connects with basic subject categories, such as change and structure. This allows a full determination of its character and cognitive functions, and facilitates the use of this concept in spatial, economic and regional analysis (Churski, 2008, p. 26).

'Development' is a component of the directional process of evolution, meaning the transition of the next generation of living organisms to a higher, increasingly diverse, complex level (Markowski, 2008, p. 13). It is influenced by various determinants whose strength, direction and range of influence change over time. Creative capital is considered to be a variable that affects the development of countries and cities. The concept of creative capital results from the theory of Florida (2010, p. 21), which defines them by presenting the assumptions of the creative class. This author states that this class derives its identity from the role of creativity providers. He points to the transformation of the economy towards a knowledge-based economy including innovation. He promotes a 'new' form of development based on a model that uses creativity. Creative class representatives settle where tolerance, talent and technology prevail. The interactions between the '3Ts' as Florida (2010) puts them in brief are expected to create the basis for economic development. Slightly controversial three criteria in economic development, referred by this author to the soft trait as creativity seems to be considered, were used in spatial research and sector comparisons. These comparisons relate to regions, countries, cities, which may indicate that these factors were considered important not only at the global level.

Local development, on the other hand, is a system of such changes that take place in a city, rural or urban-rural municipalities, or also in a delimited sub-region, i.e. a local socio-territorial system characterized by special features of space, economy and culture as well as local preferences of needs and hierarchy of values (Wojtasiewicz, 1996, p. 7).

Therefore, it is a process of diversifying and enriching economic and social activities in a given territory, consisting in the mobilization and coordination of own resources and energy. The essence of local development is not only the autonomy of an action, an independent decision about one's fate and the resulting dynamics of local initiatives, but above all the cooperation of all local 
entities and, as a result, the mobilization of environmental energy, aiming at the implementation of common, commonly accepted, long-term goals (Śniegowska, 1992, p. 88). Both technology, talent and tolerance are factors that affect local development but, according to the concept mentioned above, they also stimulate the development of creative capital.

The aim of the study is to assess one criterion included in Florida's theory; technology as determinants of creative capital development in the municipalities of the Podkarpackie Voivodeship. This goal was adopted due to the progressive development of regions, but also enterprises mainly in the technological sphere. Technical progress is taking place so quickly today, and a man equally quickly uses innovative solutions that improve their life. This results in the search for other, better technological solutions. The adoption of technology as an assessment criterion is associated not only with its importance in development, but also with spatial differentiation of regions resulting from high costs of acquiring and implementing new technologies. In the process of creation, you can create new solutions for the production process of goods.

\section{The essence of technology in relation to creative capital}

For the purposes of economic analysis technologies are defined as "the state of knowledge regarding ways of transforming resources into results, suggesting that technology can exist in both material (manifesting in products) and non-material (as projects, research results, organizational techniques). In addition to being based on knowledge, an important feature of technology is its practical application for economic purposes (Klincewicz \& Manikowski, 2013, p. 21). This definition was also adopted during the analysis of technology at the local level, showing its practical significance in the lives of residents.

Technology is the realization and, consequently, the embodiment of human ideas in matter. Technology itself is derived from a man to the extent that it is based on human nature; hence the initiative always belongs to man. On the other hand, however, man penetrates deeper into his own nature thanks to reflection on technology (van Melsen, 1969, p. 343).

Technology is associated with a specific method, process of production or information. Technology is subject to a management process that aims at: making decisions about purchasing it, introducing new solutions, and stimulate research and development. Acquisition and implementation of technology requires the involvement of interdisciplinary teams of specialists who in a given discipline develop the theoretical foundations of the production process.

At each stage of this process, a decision should be made from ideas to concept evaluation, testing or implementation. This is the transfer of technology in the economy, which results in amenities in human life. These are all stages of activity that characterize creators, innovators, designers, artists or representatives of the creative class. 
The creative class constituting the idea of Florida's theory, assessed most often according to the criterion of occupations, is an example of the definition of creative capital in a narrow approach. The author accepted that creative capital was a broader concept than the creative class and proposed its definition as a proper resource for people who cooperate and function in everyone, including in new conditions using their creativity.

Florida (2010, pp. 343-344) proposes to measure creative class development using the following indicators: the main indicator of creativity is the aggregated indicator of innovation, high technology, the number of gays (referred to tolerance) and the measures of the creative class (the number of people performing creative professions to the total number of employees - measuring talent) (Miedzianowska, 2012, pp. 86-87).

The high technology index is based on two variables - the percentage share of high-tech sector production from a given region in the total production of the entire high technology sector in the country and the percentage share of regional production from high-tech industry in the total income of the region (country).

The innovation indicator means the number of patents in a given region in a given year in relation to the number of inhabitants. The talent index (also referred to as the human capital index) presents the share of people with a bachelor's degree and higher in the entire population of a given region. These indicators were modified by various authors due to the lack of comparable basic data (Florida, 2010, pp. 343-344; Montgomery 2005, p. 338) and used to assess the intensity of the creative class in the system of countries or regions. The results of this research pointed to the development in the area of talent, technology and tolerances described in the ' $3 \mathrm{~T}$ ' model, at the same time determining the correlation between the creative class and economic development.

The indicators are used to assess countries, regions or cities, while there is no analogous data at the local level, i.e. in our case municipalities. Of course, there are indications in the literature about measuring technology through other measures.

Technology can be measured through implemented innovations, which is proposed, for example, by Godecki (2008, pp. 27-50) or by setting other indicators. For instance, 9 indicators were used to measure technology as a measure of the economic development of Eastern Poland: the share of enterprises using computers, enterprises with means of automating production processes per 1000 enterprises, the share of persons employed in R\&D, employed in R\&D to the economically active population, the share employed in modern technology enterprises, expenditure on R\&D to GDP, the share of net revenues from the sale of innovative products in industrial enterprises in total net revenues from sales, patent pending for national inventions by the Patent Office of the Republic of Poland per million inhabitants (Harasyn et al., 2018, pp. 64-76).

Regardless of the indicators used to assess technology, it is part of the environment where a man lives, also conditioning various facilities in life pre- 
ferred by representatives of the creative class. It is also what has been proven in the literature on the determinant of spatial development (Wojnicka-Sycz, 2013) and creative capital (Florida, 2010; Szara, 2017).

It should be mentioned that the introduction of new technologies is important today for modernizing the economy, restructuring enterprises and activating the workforce. One of the issues related to technology transfer is creating links between the sphere of science and the sphere of production activity. An access to public research and development activities, cooperation with universities and access to information on the results of scientific work is essential.

This seems to be important because of the growing importance of global production networks, obtaining economies of scale and diversity associated with a given stage of production and specialization. It should be mentioned about the role of the Internet, which completely changed the everyday life of people. We use mobile devices more and more often and it seems that this technology has already dominated virtually all areas of our lives.

Technological solutions are constantly changing, they are more and more advanced. An example is the promotion of computerization of production processes proposed in the draft high technology strategy of the German government, which is associated with the term Industry 4.0. This term is definitively assigned to techniques and principles of the functioning of the value chain organization using the cyber-physical system, the Internet and clouds to process and collect data. Humanity is entering a new era in which intelligent machines are supposed to make their lives easier. Already today we are in contact with artificial intelligence, electronic currency, crypto-currencies, cooperation networks, both social and business.

This causes that the barrier between people and machines disappears. This seems to be an important argument in favor of interest in technology not only because of the aspect of economic but also social benefits. To what extent will the development of technology and human creativity contribute to generating benefits, and to how much to the destruction of a man? This question is difficult to answer today, time will answer it. May creative activity in the field of technology not be harmful to humanity.

\section{Methods}

Using the available knowledge obtained from the literature on the subject regarding factors affecting local development, including creative capital, one of the possibilities is to count the indexes proposed by Florida (2010). This author also mentions in his publications a survey, however, there is no detailed description in the literature of the subject.

In the case of a spatial unit, which is a municipality, there is no possibility of aggregating data used in the Florida's methodology, including the number of professions belonging to the creative class. At least at present, it is not possible to compare the development in the local system in relation to the GDP calcu- 
lated for the municipality. When looking for features describing 3T categories, the descriptions of indicators and the basic meaning of these terms presented in the literature were used. Whereas, for the evaluation, these were the features relatively describing individual categories, indirectly proving the possibilities of creative capital development.

The technology is difficult to measure in local conditions. Indirectly the technological advancement is demonstrated by the participation of entities running business activity, the participation of newly registered entities of the creative sector. Similarly, expenditure per capita is an indirect measure indicating investment opportunities in a commune. The article presents a fragment of the analysis based on data from the Local Data Bank for 2017.

The second group of data were the assessments of the category of technology made by stakeholders living in local conditions, i.e. residents of the Podkarpackie municipalities and representatives of local authorities. The choice of statements describing in the survey was dictated by rational knowledge and the need to accept the conditions that prevail at the local level (Szara, 2017, p. 199).

The article presents the author's proposition of analyzing the ' $3 \mathrm{~T}$ ' criteria based on a diagnostic survey. The selection for analysis of the Podkarpackie Voivodeship resulted from its inclusion in the group of claimants in the development of creative capital compared to other Polish provinces (Szara, 2017, p. 164).

Due to the role of the local government unit indicated in local development, a full survey was established among all 160 municipal offices of the Podkarpackie Voivodeship. The survey was carried out using the CAWI method, preceded by telephone contact informing about the research assumption and the request to complete the questionnaire. The questionnaire was completed in 2015.

In the offices, the survey was completed by three randomly selected employees from various levels of the organizational structure. Six municipalities (Dynów, urban municipality, Gawłuszkowice, Nowa Szarzyna, Sokołów Małopolski, Strzyżów, and Żołynia) did not undergo the examination. The assumed number of three questionnaires containing answers was not obtained from five communes. From the originally adopted population of 480 subjects, 453 surveys were returned. The surveyed communes constitute $6.2 \%$ of municipalities in Poland.

The next group of respondents were residents of the Podkarpackie municipalities This selection was associated with studies of local development literature. It resulted from the statement that 3 categories of entities are recognized as participants/local stakeholders, namely decision-makers, having knowledge (experts, professionals) and all those who are active in the development of a given community (all forms and manifestations of activity of residents) or generally all entities that formulate a proposal on the political, economic, social or cultural level to better use the local development potential (Pietrzyk, 2004, p. 10). Also guided by other available studies, it was found that the community was 
involved in local development, which was a potential source of creative capital in the local space, hence the study covered municipal residents.

The survey was carried out using the PAPI method in random selection. It was assumed that about 2130 thousand people live in the Podkarpackie Voivodeship ${ }^{1}$. The fraction size was assumed to be $50 \%$, because the analyzed phenomenon related to the assessment of factors conditioning the development of creative capital at the local level was unknown. A maximum error of 5\%, significance level of $5 \%$ was taken into account, which gave a sample of 385 surveys. Due to the difficulties encountered in carrying out surveys mainly related to the incomplete completion of the questionnaire, it was adopted to carry out surveys at a level increased by 50 . This gives a statistical sample that allows obtaining some knowledge about the entire population. The thematic scope of the survey addressed to residents of municipalities was limited to the conditions of local development, taking into account creativity as the basic feature of creative capital. Data from 418 completely completed questionnaires were used for the analysis.

The adopted catalog of variables describing the technology is relative. Municipalities are open systems, that is why they are exchanged with the environment. The assessment was made on a 7 -point Likert scale, where 1 meant a very minor criterion (feature) of impact on the development of the commune, to a low degree, the lowest value, 7 very important criterion, to a very high, high degree having the highest impact ${ }^{2}$. The method of deduction, analysis and synthesis was used in developing the data obtained. In relation to own research, a hypothesis was put forward about better technology predispositions in municipalities.

This article is part of a broader analysis aimed at identifying factors related to the activation of creative capital at the local level ${ }^{3}$.

\section{Research results and discussion}

At the local level, the technology description adopts features indirectly describing this phenomenon in municipalities. This is a simplification in the research procedure, while in a relative way one can assess the predispositions of municipalities for the development of creative capital precisely using the features describing technology (table 1).

In 2017, the municipalities of the Podkarpackie Voivodeship recorded an average of 66 business entities in 2017, which was a result lower by half than in the case of Poland as a whole. This variable indirectly indicates technology and results from the need to adapt a new enterprise to market conditions. This involves equipping it with devices that do not deviate from industry standards.

1 Local Data Bank data for 2014.

21 very low impact, 2 low, 3 weak, 4 medium, 5 good, 6 very good, 7 very high impact, very important.

3 A broader analysis of the data was presented in earlier publications, among others Szara $(2017 ; 2018)$. 
The development of creative sector enterprises indirectly testifies to the use of creativity and technology transfer. On average, $5 \%$ of entities in this sector were registered in the year, which was a similar result compared to Poland $(6 \%)$. Noteworthy is the growing interest in the creative sector. The literature on the subject indicates that entrepreneurs working in this sector are younger and better educated (Kohn \& Wewel, 2018, pp. 295-318).

Natural persons were conducting economic activity per 1000 population in a lower number (52) than in Poland (78). A similar situation concerned investment expenditure per capita demonstrating the possibility of purchasing technology, which was PLN 721 lower compared to the whole country. The analysis reveals the image of the Podkarpackie municipalities with worse development conditions than in the country.

In the absence of direct data on the number of patents, expenditure on research and development, and the share of high technology production in municipalities, the above indirect measures may be used. In the author's opinion, technology can also be characterized by assessments made by respondents. They have a subjective nature, but it should be noted that they were given by people who work, live in the given municipality space. As stakeholders, they have the greatest knowledge about the state of technological advancement and its use.

Among the surveyed inhabitants of the Podkarpackie Voivodeship, the majority are young people, aged $18-24$, who constituted $69.62 \%$ of the respondents. Due to the gender, the population of the Podkarpackie Voivodeship was represented by women in $69.14 \%$ and men in $30.86 \%$. As much as $64.11 \%$ of respondents represented the rural area.

The majority of officials surveyed were also women (61.81\%). Among all respondents representing municipal offices, the largest group were people aged $25-35$ (35.32\% of respondents). In turn, $30.68 \%$ were people between the ages of 36 and 45 years old.

The dominance of high technology enterprises was considered the feature that describes technology and which was assessed by respondents. Residents of municipalities living in the local community have knowledge whether in their town there manufacturing enterprises based on advanced technological solutions. Such enterprises are often jobs for local residents. That is why, this feature was adopted by the respondents. It was rated the highest by representatives of municipalities (4.18). The weighted average responses were similar for the other two municipalities (3.89 for urban-rural and 3.69 for rural). The fact of adopting this feature for development assessment is confirmed by the studies described e.g. in the works of Correa-Quezada et al. (2018, pp. 1648-1649), Kohn \&Wewel (2018, pp. 295-318), Napadensky Pastene et al. (2018, p. 241).

The incidence and dominance of high-technology enterprises in municipalities were assessed as good by $22.49 \%$ of respondents and very good and high by over $17 \%$ of residents. As many as $14.60 \%$ considered it average, giving the score of $4,21.05 \%$ as weak (note 3 ), the others considered it low and very low. 
The analysis of the data shows that men assess the technological potential in municipalities described by the dominance of high technology enterprises slightly better than women. Disparities in assessments can also be seen between respondents living in the city and in the countryside. The weighted average answer to the above question was at 3.88.

Employees of municipalities offices assessed the dominance of high technology enterprises much lower, as much as $82.87 \%$ of responses were those with the lowest ranks ' 1 and 2' indicating an insignificant feature, very low or low in rural municipalities. In $63.44 \%$ such notes were awarded in urban-rural municipalities. The marks awarded by officials from municipalities were lower by half (33.33\%).

Small business is important in the development of technology (table 2). The weighted average rating of this feature for all municipalities was over 4 . The highest 4.57 were characteristic for rural ones. The domination of small entrepreneurship in the Podkarpackie municipalities was rated by residents at a level of $26.8 \%$. In $18.41 \%$ of cases, residents considered this trait as having the medium impact on development. The least, because only $2.64 \%$ were responses at the level of very low impact. Slightly higher the phenomenon of the occurrence of small entrepreneurship assessed the inhabitants of the village than people living in cities. The weighted average answer to the above question in the group of inhabitants was 4.38 .

Employees of municipality offices assessed the dominance of small business in $27.81 \%$ at an average level (note 4 ). A similar percentage of respondents representing rural municipalities assessed this feature similarly. Whereas the highest percentage of average ratings $33.33 \%$ was recorded for municipalities. Ratings above average, i.e. indicating good, very good and high significance of this feature dominated in urban municipalities (51.28\%). A slightly lower percentage of responses, $47.31 \%$, were recorded for urban-rural municipalities, and $39.56 \%$ for rural ones. The highest percentage of notes with a high importance of this feature was recorded for municipalities, i.e. $12.82 \%$.

When assessing the dominance of small business in municipalities, the office employees most often chose the answer with an average level of influence (27.81\%). On the other hand, $25.17 \%$ of respondents considered this trait as good. Fewer than $10 \%$ respondents gave an answer about the weak impact, and in the case of $12.14 \%$ of respondents small business was of high importance. The answers of the respondents were not very diverse due to the criteria of gender, age or education. City residents gave slightly higher marks.

The indication of the above feature as a development variable is strongly anchored in the literature. Entrepreneurship and technology are the determinants of creativity. Hence, one can conclude after J.S. Millem, that both technical progress, as well as better institutions and entrepreneurship are development factors that allow a larger accumulation of capital that is still used productively (Filipiak et al., 2005, pp. 50-51). This assessment may be supplemented by an indication of entrepreneurship in the work by Wojnicka-Sycz (2013, p. 96). 
The ability to use specialist knowledge by people in a municipality in their work and personal life was rated the highest by residents of urban-rural communes (4.60). A similar average was recorded for urban (4.48) and rural (4.40) municipalities.

The openness of people to new technological solutions is important in technology assessment, which was rated the highest by officials from municipalities (4.86). The average score for urban-rural municipalities was slightly lower in this group of respondents (4.74) as was the case for rural ones (4.45).

Progress, technology and innovation are also associated with the ability to use specialist knowledge by people in the commune at their work and in personal life. Knowledge of how to use technological 'news' is associated with the acceptance of technical progress. At the same time, it proves openness to new products and taking over the patterns of using modern solutions known in the world. The residents assessed the ability to use specialist knowledge at a good level (26.07\% of responses). A slightly smaller percentage of respondents assessed the use of knowledge at a weak level of $22.72 \%$. At a very good level, $14.83 \%$ of respondents' answers were recorded high, at 13.4\%. People aged 35-44 rated very low the use of knowledge.

The ability to use specialist knowledge was most often assessed by employees of municipal offices at the average level (41.06\%). The next most frequently given answers were grades with good (fairly high) and poor use of knowledge (24.94\% and $17.66 \%$, respectively). The importance of this feature in shaping the competitive advantage of cities and regions was noted by Malecki (1987, pp. 205-222). Specialist knowledge is a value appreciated by employers, which is shown in studies, e.g. Bouckenooghe \& Menguc (2018) or Comunian \& Jewell (2018, pp. 205-230), Faggian et al. (2017, pp. 997-1009), Szelągowska-Rudzka (2017, pp. 131-148).

The technological advancement is demonstrated by an implementation of innovations in enterprises in a municipality. These new technological solutions are often used by residents who rated this feature at an average level of 4.72 . For the other two municipalities the average grade was 4.56. The answer shows that the features describing the technology in the municipality were rated at an average level (note 4). Municipal communes were slightly higher.

In the opinion of officials the implementation of innovation in enterprises in municipalities was assessed at an average level (32.89\% of scores 4). According to $29.58 \%$ of respondents the scale of the phenomenon was considered weak, and $14.79 \%$ rated it at a low level. Fewer than 5\% of respondents stated very low importance of innovation in enterprises. On the other hand, 13.47\% of employees of municipal offices assessed the implementation of innovations at a good level.

This feature was rated much higher by employees of municipality offices living in the city (3.92), compared to the residents of the village (3.33).

Almost 25\% higher percentage of negative indications in the case of representatives of municipal offices in the assessment of this feature was recorded for 
rural communes (55.14\%). There were fewer negative ratings for the other two types: $36.56 \%$ urban-rural and $30.77 \%$ urban ones. The assessments of the average impact of ' 4 ' were recorded in $32.89 \%$ of cases, and the highest percentage was found in urban and rural municipalities - 40.86\%.

Residents indicated that they are open to new technological solutions, while this openness was rated at a good level of $23.92 \%$. Over $30 \%$ of respondents said that people's openness to technology transfer was both very good and high. In contrast, $19.10 \%$ considered this phenomenon to be average. Others rated them even lower. The answer structure shows that the residents are open to new technological solutions that are implemented in municipalities. The weighted average answer to the above question was 4.64 . The data on the innovation implementation do not differ from the results regarding the introduction of innovative solutions in the literature on the subject (Hollanders \& Cruysen, 2009, p. 7; Kaczmarek-Krawczyk, 2016, pp. 99-108).

In the opinion of officials, openness of people to new technological solutions was similarly assessed at the average level (32.45\%). The highest number of such notes was recorded for $33.96 \%$ of rural municipalities.

Respondents representing urban communes indicated $38.46 \%$ of the answers above the note 4 , which meant the importance of the feature. In the case of respondents from these communes, the lowest percentage of responses low significance of this feature was recorded (33.33\%). Respondents of rural municipalities $(51.09 \%)$ chose the highest percentage of negative ratings (notes 1 and 2).

The openness of people to new technological solutions was most often rated as poor (score $3-33.33 \%$ of responses). A slightly smaller percentage $(32.45 \%)$ were answers with an average rating (note 4$)$. Only $14.79 \%$ openness to technology was rated as good. The results confirm that natural regularity should be borne in mind, expressed in a wide variety of municipalities in many respects. The openness to new technologies is a future feature associated with learning to 'handle' technical novelties (Batabyal \& Beldi, 2018, pp. 214-219; Klasik \& Kuźnik, 2007, p. 6; Sipa, 2018, pp. 1-13).

The research results obtained usually indicate an assessment of the technological potential of municipalities at an average level. There are assessments predestinating urban communes (which allows confirming the hypothesis adopted), but rural communes also have the potential for local development supported by technology. Higher creative capital development preferences in urban areas correspond to the results of other authors (Gonzalez et al., 2018, pp. 149-186; He \& Husang, 2018, pp. 79-96; Seman \& Carroll, 2017, pp. 831-852). The results testify to the technological potential of the Podkarpackie municipalities, which means favorable conditions within this criterion for the development of creative capital if the results are referred to Florida's theory. Basing on only one criterion does not disqualify municipalities and indicates the possibility of comparisons in the category of talent and tolerance. It is also a starting point 
for the possibility of comparison based on other indicators characterizing e.g. information society and indirectly also technology.

\section{Conclusions}

The author's modification of Florida's methodology related to one of the criteria mentioned in the assessment, i.e. technology is a novelty in the research approach. It is also a new approach to the analysis of technology as a determinant not only of local development, but also of creative capital. This new approach involves the adoption of other variables for technology assessment at the local level, not by presenting it in the context of innovation as it is often done in the literature on spatial development. The approach presented may give rise to a discussion in the area of the lack of proof of relationships between people included in the creative capital. However, the participation of newly-registered creative sector enterprises indirectly confirms the occurrence of these relationships.

The connection between spatial development factors with technology is not a new phenomenon. In local development, the differentiation of municipalities due to technological development is associated with the possibility of investing. The better conditions for investment development and capital inflow we have in municipalities, the better opportunities they have for the development of enterprises and also creative capital. In the case of local development, however, relying on the technology factor is associated with its inflow from outside, which means the cost of its acquisition. In the case of creativity and building creative capital, as well as its inclusion in local development, it is important to pay attention to internal resources as they predestine the commune's society for development. Therefore, the study includes features that are soft in nature. They describe local conditions, and at the same time are reflected in the attitudes of residents and the reflection in local development.

The respondents' assessment shows that technological conditions in municipalities best describe an ability of their inhabitants to use specialist knowledge in work and personal life. This is primarily due to the absorption of knowledge about technological novelties, which in the era of IT, mobile telephony and video games is not difficult, especially since young people want to have such devices. The second position in the ranking, namely development of entrepreneurship shows that municipalities are moving in this direction, they create conditions for business development which should be assessed positively, after all entrepreneurs are creators of their own businesses. Technology determines development, also indicates the advancement of society, is important at the global level but also at the local one, which is confirmed by the answers regarding openness to new technologies. A comparison of both groups of respondents shows that the possibilities of developing creative capital through the prism of technology were assessed by residents of municipalities rather than by officials. 


\section{References}

Batabyal, A., \& Beldi, H. (2018) Artist, engineers and aspects of economic growth in a creative region. Economic Modelling, 71. doi:10.1016/j. econmod.2017.12.013.

Bouckenooghe, D., \& Menguc, B. (2018). Understanding the dynamics between supervisor-follower social capital, work engagement, and employees' creative work involvement. Canadian Journal of Administrative Science, 35(2). doi:10.1002/cjas.1427.

Churski, P. (2008). Czynniki rozwoju regionalnego i polityka regionalna w Polsce w okresie integracji z Unią Europejską. Poznań: UAM.

Comunian, R., \& Jewell, S. (2018). 'Young, talent and highly mobile': exploring creative human capital and graudates mobility in the UK. In B. Biagi, A. Faggian, I. Rajbhandari, \& V.A. Venhorst (Eds.), New frontiers in interregional migration research. Cham: Springer.

Correa-Quezada, R., Alvarez-Garcia J., de la Cruz del Rio-Rama, M., \& Maldonado-Erazo, C. (2018). Role of creative industries as a regional growth factor. Sustainability, 10(5). doi:10.3390/sul0051649.

Faggian, A., Partridge, M., \& Malecki, E. (2017). Creating an environment for economicgrowth: creativity, entrepreneurshipor human capital? International Journal of Urban and Regional Research, 41(6). doi:10.1111/1468-2427.12555.

Filipiak, B., Kogut, M., Szewczuk, A., \& Zioło, M. (2005). Rozwój lokalny i regionalny: uwarunkowania, finanse, procedury. Szczecin: Fundacja na rzecz Uniwersytetu Szczecińskiego.

Florida, R. (2010) Narodziny klasy kreatywnej oraz jej wptyw na przeobrażenia w charakterze pracy, wypoczynku, spoteczeństwa i życia codziennego. Warszawa: NCK.

Godecki, T. (2008). Pomiar innowacyjności gospodarki przy użyciu pośrednich i bezpośrednich wskaźników innowacji. Zarządzanie Publiczne, 5(3).

Gonzalez, A., Segovia, M., \& Sanchez, F. (2018). Spatial distribution of a creativity index at municipal level in Mexico. Estudios Demográficos Y Urbanos, 33(1).

Harasyn, R., Pater, R., \& Skica, T. (2018). Konkurencyjność i rozwój Polski Wschodniej. Samorząd Terytorialny, 5.

He, J., \& Husang, X. (2018). Agglomeration, differentiation and creative milieux: a socioeconomic analysis of location behaviour of creative enterprises in Shanghai. Urban Policy and Research, 36(1). doi:10.1080/08111146.2016.1 235035.

Hollanders, H., \& Cruysen, A. (2009). Design, creativity and innovation: a scoreboard approach. Retrieved 06.12.2019 from https://www.semanticscholar. org.

Kaczmarek-Krawczyk, J. (2016). Wdrażanie innowacji w sektorze małych i średnich przedsiębiorstw na przykładzie regionu łódzkiego. Przedsiębiorczość Międzynarodowa, 2(1). 
Klasik, A., \& Kuźnik, R. (2007). Regiony uczące się w teorii i polityce rozwoju regionalnego. In A. Jewtuchowicz (Ed.), Region $w$ gospodarce opartej na wiedzy. Łódź: UŁ.

Klincewicz, K., \& Manikowski, A. (2013). Ocena, rankingowanie i selekcja technologii. Warszawa: UW.

Kohn, K., \& Wewel, S.A. (2018). Skills, scope and success: an empirical look at the start-up process in creative industries in Germany. Creativity and Innovation Management, 27(3). doi:10.1111/caim.12279.

Malecki, E.J. (1987). The R\&D location decision of the firm and 'creative' regions: a survey. Technovation, 6(3). doi:10.1016/0166-4972(87)90023-x.

Markowski, T. (2008). Teoretyczne podstawy rozwoju lokalnego i regionalnego. In Z. Strzelecki (Ed.), Gospodarka regionalna i lokalna. Warszawa: PWN.

Miedzianowska, M. (2012). Klasa kreatywna a kapitał ludzki i kapitał społeczny. In K. Klincewicz (Ed.), Klasa kreatywna w Polsce: technologia, talent i tolerancja jako źródta rozwoju regionalnego. Warszawa: UW.

Montgomery, J. (2005). Beware 'the creative class': creativity and wealth creation revisited. Local Economy: The Journal of the Local Economy Policy Unit, 20(4). doi:10.1080/02690940500298706.

Napadensky Pastene, A., Villouta Gutierrez, D., \& Farias Olavarria, F. (2018). City for creatives: what attracts and repeats the greater conception area, Chile. Distances between global and local discourses. Architecture City and Environment, 13(37). doi:10.5821/ace.13.37.5276.

Pietrzyk, I. (2004). Globalizacja, integracja europejska a rozwój regionalny. In A. Jewtuchowicz (Ed.), Wiedza, innowacyjność, przedsiębiorczość a rozwój regionów. Łódź: UŁ.

Seman, M., \& Carroll, M.C. (2017). The creative economies of Texas metropolitan regions: a comparative analysis before, during, and after the recession. Growth and Change, 48(4). doi:10.1111/grow.12198.

Sipa, M. (2018). The factors determining the creativity of the human capital in the conditions of sustainable development. European Journal of Sustainable Development, 7(2). doi:10.14207/ejsd.2018.v7n2pl.

Śniegowska, D. (1992). Samorząd terytorialny a rozwój gospodarki lokalnej. Zeszyty Naukowe Akademii Ekonomicznej w Poznaniu, 205.

Szara, K. (2017). Uwarunkowania i możliwości aktywizacji kapitału kreatywnego jako determinanty rozwoju lokalnego na przyktadzie gmin województwa podkarpackiego. Rzeszów: UR.

Szara, K. (2018). Determinants of creative capital development at a local level: case study municipalities of Podkarpackie, Poland. Lex Localis: Journal of Local Self Government, 16(3). doi:10.4335/16.3.529-549(2018).

Szelągowska-Rudzka, K. (2017). Employee direct participation in organizational change process: pilot study report. In A. Nalepka, \& A. Ujwary-Gil (Eds.), Business and non-profit organizations facing increased competitions and growing customers' demands. Nowy Sącz: Wyższa Szkoła Biznesu; Nowy Targ: Foundation for the Dissemination of Knowledge and Science 'Cognitione'. 
van Melsen, A.G. (1969). Nauka i technologia a kultura. Warszawa: PAX. Wojnicka-Sycz, E. (2013). Model terytorialnego bieguna wzrostu jako systemu czynników rozwojowych. Gdańsk: UG.

Wojtasiewicz, L. (1996). Czynniki i bariery rozwoju lokalnego w aktualnej polityce gospodarczej Polski. Prace Naukowe Akademii Ekonomicznej we Wroctawiu, 734.

\section{Acknowledgements}

Author contributions: author has given an approval to the final version of the article.

Funding: this research was funded by the University of Rzeszów, Faculty of Economics statutory sources.

Note: the results of this study were presented at International Scientific Practical Conference Cooperation between higher education and world of work: sustainable, innovative and creative perspective (May 10-11, 2018, Vilnius, Lithuania); International Scientific Conference Economic Sciences for Agribusiness and Rural Economy (June 7-8, 2018, Warsaw, Poland); 3rd Scientific Conference Effectiveness and debt problem of local government units (June 14-15, 2018, Rzeszów, Poland) and 10th International Conference on Applied Economics Contemporary Issues in Economy (June 27-28, 2019, Torun, Poland). 


\section{Appendix}

Table 1.

Basic descriptive statistics of the characteristics of the technology

\begin{tabular}{lcccr}
\hline \multicolumn{1}{c}{ Specification } & Mean & Standard deviation & Change mentioned & Kurtosis \\
\hline $\begin{array}{l}\text { entities entered in the register per 1000 } \\
\text { population }\end{array}$ & 66.60 & 22.89 & 3437.00 & 5.40 \\
$\begin{array}{l}\text { natural persons running economic activity } \\
\text { perl000 population }\end{array}$ & 51.96 & 17.34 & 33.38 & 5.40 \\
$\begin{array}{l}\text { share of newly registered creative sector entities } \\
\text { in the total number of newly registered entities }\end{array}$ & 5.11 & 3.30 & 64.58 & -0.51 \\
\begin{tabular}{l} 
expenses per capita \\
\hline
\end{tabular} & 3705.70 & 536.22 & 14.47 & 13.90 \\
\hline
\end{tabular}

Source: Own preparation.

Table 2.

Ranking of features describing technology categories

\begin{tabular}{|c|c|c|c|c|c|c|}
\hline Features description & $\begin{array}{c}\text { Municipality } \\
\text { offices }\end{array}$ & Ranking & Residents & Ranking & Total & Ranking \\
\hline $\begin{array}{l}\text { an ability to use specialist knowledge } \\
\text { by the municipality residents for work } \\
\text { and personal life }\end{array}$ & 4.15 & 1 & 4.49 & 3 & 4.32 & 1 \\
\hline dominance of small business & 4.12 & 2 & 4.38 & 4 & 4.25 & 2 \\
\hline $\begin{array}{l}\text { people's openness to new technological } \\
\text { solutions }\end{array}$ & 3.61 & 3 & 4.65 & 1 & 4.13 & 3 \\
\hline $\begin{array}{l}\text { an implementation of innovations } \\
\text { in enterprises in the municipality }\end{array}$ & 3.51 & 4 & 4.61 & 2 & 4.06 & 4 \\
\hline dominance of high technology enterprises & 2.02 & 5 & 3.88 & 5 & 2.95 & 5 \\
\hline
\end{tabular}

Source: Own preparation. 